Bangladesh J. Plant Taxon. 16(2): 177-180, 2009 (December)

(C) 2009 Bangladesh Association of Plant Taxonomists

- Short communication

\title{
EPIDERMAL FEATURES OF RICE LEAF CV. BRRI DHAN29
}

\author{
MD. TOFAzZAL ISLAM ${ }^{1}$, A.K.M. Golam SARWAR ${ }^{2}$, \\ Hasna Hena Begum and Toshiaki Ito \\ Research Faculty of Agriculture, Hokkaido University, Kita 9, Nishi 9, \\ Kita-Ku, Sapporo 060 8589, Japan.
}

Keywords: Leaf epidermis; Rice; Scanning electron microscopy (SEM); Slender macro hair.

Epidermal characters of the leaf play an important role in distinguishing members of the Poaceae (Metcalfe, 1960; Ellis, 1979) as well as different rice (Oryza sativa L.) cultivars (Sarwar and Ali, 2002 and references therein). With the increased use of electron microscopy, studies on phytoliths as criteria in systematics have successfully been employed (Whang et al., 1998).

Among 51 high yielding rice cultivars developed by Bangladesh Rice Research Institute (BRRI), the BRRI dhan29 is one of the most productive and popular cultivars (Anonymous, 2009). A detail light microscopic (LM) study on leaf epidermis of some rice cultivars grown in Bangladesh was carried out (Sarwar and Ali, 2002), but no scanning electron microscopic (SEM) study on the leaf epidermis of them has been done. The present study was carried out to visualize the characteristic features of leaf epidermis of BRRI dhan29 by SEM.

BRRI dhan29 seeds collected from the seed market of Mymensingh, Bangladesh were sterilized, germinated and after two weeks culture the third leaves were prepared for SEM study following protocol as described by Islam et al. (2005). The stomatal apparatus, macro hairs, and prickle hairs were measured under a JSM-6301F, JEOL scanning electron microscope with accelerating voltage of $5 \mathrm{kV}$.

The leaf surface of BRRI dhan29 comprises several types of cells and appendages e.g., long and short cells, stomata with guard cells, macro hairs, prickle hairs, papillae and silica bodies (Figs 1A-D). The long cells were dominating among the various cells. The whole leaf surface had a dense cover of epicuticular wax and bore hairs. Long cells of both costal and intercostal regions had thick and moderately marked sinuous wall (Figs 1C, F). By LM, similar results were reported by Sarwar and Ali (2002).

Short cells were usually nearly equidimensional in shape and were present in costal regions and absent in intercostal regions (Fig. 1A). It also confirmed the earlier reports of LM studies (Metcalfe, 1960; Sarwar and Ali, 2002). Papillae are protrusions of various shapes and sizes from the outer walls of the epidermal cells. The number and size of papillae varied among different cells and within a cell also (Figs 1C, F, G).

1 Present address: School of Agriculture and Rural Development, Bangladesh Open University, Gazipur, Bangladesh. E-mail: tofazzalislam@yahoo.com

2 Corresponding author. Present address: Department of Crop Botany, Bangladesh Agricultural University, Mymensingh 2202, Bangladesh. E-mail: gsshameem@gmail.com 
Macro hairs were common in the adaxial surface along with other types of hairs (Figs 1B, D, G). Macro hairs were characteristically unicellular with pointed tip (Figs 1B, G) and were seen with naked eye or by a hand lens (Metcalfe, 1960; Ellis, 1979; Sarwar and Ali, 2002). The length of macro hairs was 87.75 (mean) \pm 14.72 (standard deviation) $\mu \mathrm{m}$ and the width was $14.02 \pm 1.60 \mu \mathrm{m}$. But, a special type of macro hair was discovered in both the adaxial and abaxial surfaces of rice leaves in this study (Figs 1D, E). These macro hairs are small and slender in shape with blunt tip, length $32.63 \pm 7.65 \mu \mathrm{m}$ and width $5.21 \pm 0.70 \mu \mathrm{m}$ (Fig. $1 \mathrm{H}$ ). This is the first report on the presence of slender macro hair on the rice leaf epidermis, although this type of macro hairs was observed on the adaxial surface of mature maize leaf (Fig. 1B in Sylvester et al., 2001). Sylvester et al. (2001) also did not find any difference in the anatomy of juvenile leaves of rice compared with that of adults. The BRRI dhan29 bears the highest density of macro hairs on its leaf epidermis (Sarwar and Ali, 2002), which might be one of the probable causes of resistance to insect pests and diseases in this cultivar. But further studies, with both higher number of cultivars and specimens, are needed to confirm whether this feature is unique to this cultivar or also shared with others.
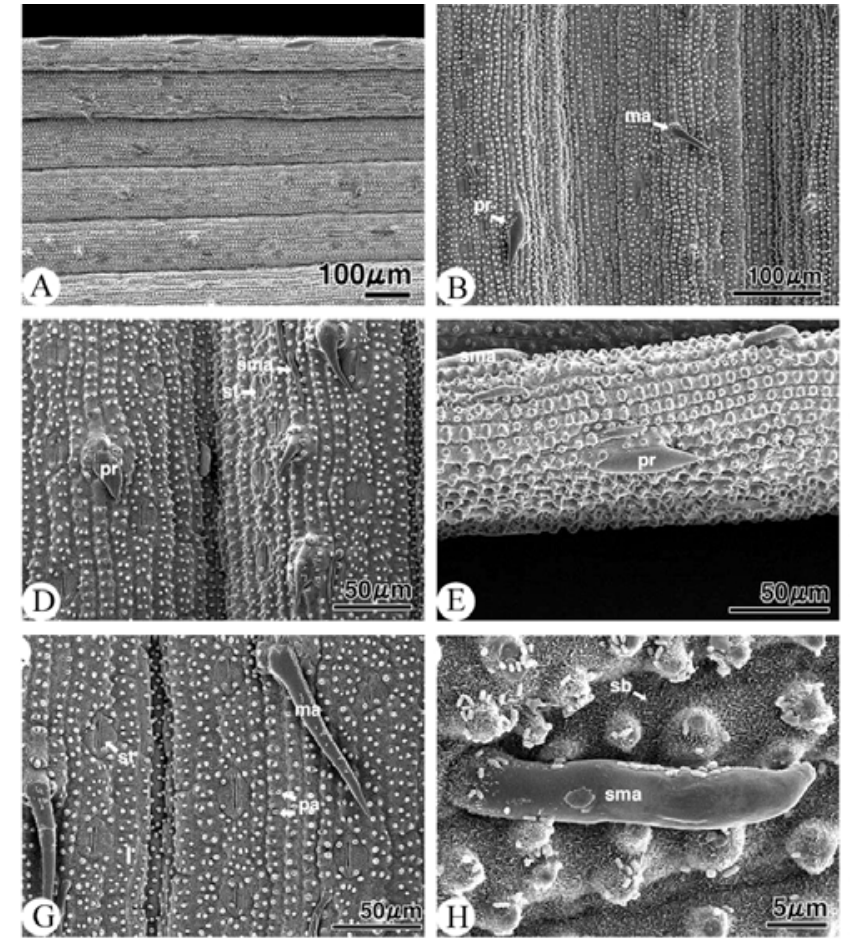

Fig. 1. Scanning electron micrographs showing the adaxial (A-D, F, G, I) and abaxial (E, H) surfaces of BRRI dhan29 leaf blade. The leaf surfaces contain long cells, short cells, prickle hairs, stomata with guard cells, papillae and hairs of different sizes. l, long cell; ma, macro hair; pa, papilla; pr, prickle hair; sb, silica body; sma, special type macro hair; st, stoma with guard cells. Rods on figure $\mathrm{H}$ are phyloplane epiphytic bacteria. 
The stomata were arranged in 3-4 rows in intercostal zones (Fig. 1B). The stomatal apparatuses were generally triangular in shape, but some were found to be dome shaped (Figs 1C, F, G). The frequency of stomata was higher in the adaxial surface compared with the abaxial surface. The length of stomatal apparatuses was $27.67 \pm 2.86 \mu \mathrm{m}$ and the width was 17.07 $\pm 2.71 \mu \mathrm{m}$. Similar observations were reported from LM studies (Sarwar and Ali, 2002), but the present study visualized the epidermal characteristics of BRRI dhan29 rice leaves more clearly and in depth. The size, shape and number of stomata might be used as differentiating criteria of rice cultivars grown in Bangladesh (A.K.M. Golam Sarwar, unpublished data).

Most silica bodies are formed in epidermal long cells (Figs 1F, H). Silica bodies developed in epidermal long cells along the midrib were significantly different in shape and size compared to those formed along other veins. Morphological variations in silica bodies might be related to different water conducting tissue systems that influence silica availability, phytolith size and shape (Whang et al., 1998). In rice, silica body content may be correlated with resistance to fungal diseases (e.g., brown spot and blast) and insect pests (e.g., Asiatic stem borer and leaf roller) (Kim et al., 2002). The number of silica bodies and rows per cell may be diagnostic for a species, but there is always a range of values, and variations are due to the age of the leaf, and environmental conditions must be taken into account (Kim et al., 2002; Prychid et al., 2003). The X-ray micro-analysis is emerged as a good tool for quantifying Si distribution in the rice leaf (Lux et al., 1999, 2003).

In the abaxial epidermis, prickle hairs were fairly common (Fig. 1E). Prickle hairs had tough, short pointed structure with swollen bases and short, sharp pointed spines or barbs which arise from (Fig. 1I), and form an integral part of epidermis with lignified walls (Metcalfe, 1960). The length of prickle hairs was $66.1 \pm 15.57 \mu \mathrm{m}$ and the width was $19.1 \pm 2.36 \mu \mathrm{m}$. The leaf margin was characterized by the radial arrangement of prickle hairs only (Sarwar and Ali, 2002). They were distributed more or less equidistantly in BRRI dhan29 (Fig. 1A).

\section{Acknowledgements}

The authors are thankful to Prof. Satoshi Tahara, Laboratory of Ecological Chemistry, Hokkaido University, Japan for his enormous support during this work. The first author and the corresponding author are thankful to the Japan Society for the Promotion of Science (JSPS) and Ministry of Education, Culture, Sports, Science and Technology (MEXT) of Japan for the Postdoctoral Fellowship and Monbukagakusho Scholarship during the period of this study, respectively. 


\section{References}

Anonymous 2009. Success stories. <http://www.brri.gov.bd/success_stories/index.htm>, retrieved on 10 April 2009.

Ellis, P.R. 1979. A procedure for standardizing comparative leaf anatomy in Poaceae. II. The epidermis as seen under surface view. Bothlia 12: 641-671.

Islam, M.T., Deora, A., Hashidoko, Y., Ito, T. and Tahara, S. 2005. Suppression of damping-off disease in host plants by the rhizoplane bacterium Lysobacter sp. Strain SB-K88 is linked to plant colonization and antibiosis against soilborne Peronosporomycetes. Appl. Environ. Microbiol 71: 3786-3796.

Kim, S.G., Kim, K.W., Park, E.W. and Choi, D. 2002. Silicon-induced cell wall fortification of rice leaves: A possible cellular mechanism of enhanced host resistance to blast. Phytopathology 92:1095-1103.

Lux, A., Luxova, M., Abe, J., Morita, S. and Inanaga, S. 2003. Silicification of bamboo (Phyllostachys hetercycla Mitf.) root and leaf. Plant and Soil 255: 85-91.

Lux, A., Luxova, M., Morita, S., Abe, J. and Inanaga, S. 1999. Endodermal silicification in developing seminal roots of lowland and upland cultivars of rice (Oryza sativa L.). Can. J. Bot. 77: 955-960.

Metcalfe, C.R. 1960. Anatomy of Monocotyledons. I. Gramineae. Oxford Univ. Press, London, pp. 1-731.

Prychid, C.G., Rudall, P.J. and Gregory, M. 2003. Systematics and biology of silica bodies in Monocotyledons. Bot. Rev. 69: 377-440.

Sarwar, A.K.M. Golam and Ali, M.A. 2002. Studies on the leaf epidermis of rice (Oryza sativa L.). Indian J. Agric. Res. 36: 24-28.

Sylvester, A.W., Parker-Clark, V. and Murray, G.A. 2001. Leaf shape and anatomy as indicators of phase change in the grasses: comparison of maize, rice, and bluegrass. Amer. J. Bot. 88: 2157-2167.

Whang, S.S., Kim, K. and Hess, W.M. 1998. Variation of silica bodies in leaf epidermal long cells within and among seventeen species of Oryza (Poaceae). Amer. J. Bot. 85: 461-466.

(Manuscript received on 10 April 2009; revised on 7 July 2009) 